\title{
REGIONAL SEMINAR FOR EASTERN AFRICAN RED CROSS AND RED CRESCENT SOCIETIES
}

Meetings are arranged in various parts of the world, under the auspices of the League of Red Cross Societies, to enable National Societies together to examine problems which they have to face. These are each time described in the International Review, which published two articles in this connection in its last issue, one of which dealt with the VIIIth Inter-American Red Cross Conference held in Bogota in 1966 and the other with the Inter-American Seminar on Junior Red Cross and Health Education which took place shortly before at Quito.

We now have pleasure in publishing an article on the Seminar of Addis Ababa whose significance it is unnecessary to emphasize, following as it does those held on the African continent, in Abidjan in 1965 and Rabat in 1956. (Ed.).

This Seminar was held in Africa Hall, Addis Ababa, from 9th to 19th January 1967, under the auspices of the League of Red Cross Societies and attended by the Red Cross or Red Crescent Societies of Burundi, Ethiopia (the host Society), Kenya, Somalia, Sudan, Tanzania, Uganda and Zambia. The League was represented by Mr. Kai J. Warras, Chairman of the Development Programme Advisory Panel, Major General A. Wrinch, National Commissioner of the Canadian Red Cross, Mrs. Le Meitour-Kaplun, Advisor on Health Education, Mr. P. Stanissis, Regional Delegate for Central Africa and Mr. N. Phillips, Desk Officer for Africa. The ICRC was represented by Mr. G. Hoffmann, delegate general for Africa. In addition, the National Red Cross Societies of Canada, Liberia and the USSR had nominated observers and they were joined by a number of observers from governmental and non-governmental organisations, both Ethiopian and international, including the Economic Commission for Africa, UNESCO and the International Labour Organisation, whose presence contributed greatly to the efficacity of the discussions. 
The dual capacity of General Wrinch, as a League delegate and as an observer of his National Society, was a tribute to the Canadian Red Cross for its generous financial contribution which made the Seminar possible.

The Seminar was opened by His Imperial Highness the Crown Prince Merid Azmatch Asfaw Wossen, President of the Ethiopian Red Cross Society, and a message was read from His Imperial Majesty the Emperor of Ethiopia ${ }^{1}$. The Ethiopian Red Cross Society had taken infinite pains in every aspect of the organisation of the Seminar and it was fitting that the Vice President of the Ethiopian Red Cross, His Excellency Tsahafi Tezaz Tafarra Worq, should have been elected Chairman of the Seminar. Mr. Warras was elected Vice-Chairman and Director of the Seminar.

The subjects discussed were-The Choice of Programme Priorities for new National Societies ; Information and Publicity; Fund-raising and Membership Recruitment; Disaster Relief Preparedness; the Role of the ICRC and of National Societies in Time of Conflict; Young People in the Red Cross and Opportunities for Action, the last subject being directly related to the Role of Young People in the Red Cross. Obviously, in a general seminar of this nature, it was not always possible to examine all the aspects of these subjects in great detail. Interest, however, was at a generally high level throughout and it is difficult to single out the high point of the Seminar. Perhaps the subjects which aroused the most interest and discussion were Fund-raising, Disaster Relief Preparedness and the Role of Young People in the Red Cross :Fund-raising, because this is a crucial problem for every National Society which was represented at the Seminar; Disaster Relief because this brought home very clearly to the participants the enormous responsibility which National Red Cross Societies have in this field and for which many of them are only beginning to prepare themselves; and the Role of Young People in the Red Cross because in practically every National Society represented at the Addis Ababa Seminar junior members outnumber adult members.

${ }^{1}$ Plate. The Seminar is opened by His Imperial Highness the Crown Prince, President of the Ethiopian Red Cross Society. 


\section{IN THE Red Cross World}

The Seminar voted Recommendations on the subjects discussed which will undoubtedly have their influence on the work of the Red Cross and Red Crescent in Eastern Africa in the coming years. Recommendations IV and $\mathrm{V}$ which are of general interest are given below ${ }^{1}$ :

\section{Recommendation IV}

The Regional Seminar for Eastern African Red Cross and Red Crescent Societies.

\section{NOTING :}

The vital necessity for quick, immediate and suitable action in the event of disaster ;

\section{NOTING :}

The need for effective co-ordination in the field of disaster relief with the aim of ensuring the best possible organisation;

\section{NOTING :}

The imperative need for pre-disaster planning:

\section{RECALLS :}

To all National Societies the United Nations resolution No 2034 and resolution $N^{\circ}$ XVII of the XXth International Red Cross Conference :

NOTES :

That the League Secretariat has undertaken steps to draw up a draft plan for the setting up in each country of a national relief organisation, and that expert advice will be available through the Development Programme to countries requesting assistance in formulating such a plan;

1 Recommendation $\mathrm{V}$ concerns the dissemination of knowledge on the Geneva Conventions. In this connection we would mention that Mr. G. Hoffmann had the opportunity to recall the ICRC's role as the guardian of the Conventions, its activities in Africa, and the tasks incumbent on a National Society in times of conflict $(E d$.$) .$ 


\section{IN THE Red Cross WORLD}

\section{RECOMMENDS :}

The immediate implementation of pre-disaster planning for minor and major disasters, including :

- the establishment of a National Disaster Relief Committee in each country, to include governmental and voluntary agencies as well as the National Society, together with other organisations with a role to play.in the field of disaster relief;

- the assessment of the likelihood of disasters in various parts of the country, classification of disasters by type and magnitude, and preparation of plans accordingly:

- a clear definition of the responsibilities of all groups concerned, in the event of disaster :

noting that governmental responsibilities could include such items as warning of danger, evacuation, rescue, maintenance of law and order, fire precaution and protection, public health and sanitation, care of the dead, traffic control and provision of services which are the normal responsibility of government;

whilst Red Cross responsibilities should be concerned, amongst other things, with primary emergency needs such as shelter, food, clothing, first aid and medical care depending upon the magnitude of the disaster ;

\section{FURTHER RECOMMENDS :}

\section{To National Societies}

- that in addition to giving courses of instruction to the public, they make every effort to establish trained units of volunteers to be available for action in the event of disaster, and that such units be kept active through training programmes and participation in specific Red Cross projects such as health education programmes in cities, towns and villages;

- that in the event of disaster an immediate survey be undertakenbearing in mind the communications systems available to Red Cross through prior arrangement with the relevant authoritiesand that such survey should enable an estimate to be made of needs in order to determine whether local or national resources 


\section{IN THE ReD Cross WorLd}

will suffice or whether, in the last resort, an appeal will be made to the League of Red Cross Societies for assistance from sister National Societies.

\section{Recommendation $\mathbf{V}$}

The Regional Seminar for Eastern African Red Cross and Red Crescent Societies :

\section{CONSIDERING :}

That the dissemination of the knowledge of the Geneva Conventions in peace time is essential for their adequate application in war;

\section{CONSIDERING :}

That members of Armed Forces and all medical personnel in the first place should be familiar with the rules of the Geneva Conventions;

\section{RECOMMENDS :}

That the National Red Cross and Red Crescent Societies follow up the question of the propagation of the Geneva Conventions in continuous contact with the competent authorities, in order to ensure that the syllabus used in the professional preparation of army officers, of doctors, of nurses and of teachers, gives adequate consideration to the matter of the Geneva Conventions and the International Red Cross.

Recommendation VI deals in particular with the Junior Red Cross and Health Education. It draws attention first of all to certain important aspects of the development of a section of young people. Then the Seminar

\section{RECOMMENDS :}

To National Societies that, in a first stage, they concentrate on the development of activities in schools, two major factors of success being

- the full support of the education authorities, who should be made to understand the contribution Red Cross can make to the social education of youth and how Red Cross can supplement the school programme. 


\section{IN THE RED Cross WORLD}

- the equally full support of the teacher corps, including the headmasters of schools, who need to receive adequate training on the Red Cross-a most effective way being to educate future teachers when they are in teacher training colleges;

\section{URGES :}

National Societies, in addition, to obtain from the education authorities that teaching on Red Cross be integrated in the teaching of other school subjects, namely through

- a government decree making this integrated teaching official,

- cooperation in the drafting of textbooks including information on Red Cross principles, the Geneva Conventions, etc.,

- providing teachers with guidelines which they can use in their teaching on Red Cross (a basic document from the League and ICRC is a definite need in this respect);

\section{ENCOURAGES :}

National Societies to try and enroll youth out of School as well, some of the effective means suggested including

- reaching young people through rural health centres, camps and clubs for youth out of school, village gatherings in the evening, community centres, churches, etc.,

- turning for leadership to health workers, community development workers and other key community persons, their support being invited preferably as Red Cross volunteers themselves ;

\section{FEELS :}

That when it comes to planning programmes for young people it is most important that National Societies should take into careful consideration the needs, interests and demands of young people, especially the following points :

- young people are idealistic and want guidance into becoming useful citizens; they want action, i.e. tangible programmes and not just theoretical training; they want to be of service to others; they want education-which can help them get ahead in life and 


\section{IN THE RED CROSS WORLD}

choose a career; they need drama in their programmes; and last but not least they want to be given responsibilities ;

\section{RECOGNISES :}

That unless a National Society develops meaningful activities answering the above needs and taking cultural patterns into consideration, it will not attract to its ranks young people, as they have many other opportunities to use their leisure time...

Finally, this Recommendation requests National Societies 1) to encourage the promotion in schools of activities leading to health education ; 2) to provide young people with the means of taking part in communal activities of health education and 3) forge a link between the work of health education and that whose purpose is to foster international understanding. 4) in conclusion of the recommendation, the Seminar

\section{EXPRESSES}

Its conviction that health activities lead naturally to service to others, which in turn leads to international understanding, international friendship and peace, and that health education therefore can provide youth with the challenging work they demand and lead them to become effective senior members of the Red Cross and of mankind.

The Recommendations in themselves cannot, of course, communicate the atmosphere of the Seminar. For many of the participants it was the first occasion on which they had been able to meet some of their colleagues from sister Societies. The occasion was an encouraging re-affirmation of the internationality of Red Cross and of the determination of men and women of goodwill to set aside the differences which divide nations and to work together to solve their problems inspired by the principles of the Red Cross, which are of universal validity.

The Chairman of the Seminar, H. E. Tsahafi Tezaz Tafarra Worq, summed up this feeling in his closing speech when he said "I am convinced that this gathering has not only produced positive contributions to the solutions of the problems we have met to consider but, as well, has marked the start of a closer relationship among us all. We have considered during our meetings here a wide 
variety of issues. All of them bear one common mark-they are aimed at the relief of those in need, at the alleviation of those in suffering, at the improvement of standards of health and hygiene. No one of these is more important than any other. Disaster Relief, Health Education, Youth, the Problems of National and International Conflicts, all touch and deal with the most basic fields of humanity and brotherhood. I am in complete accord with the theme adopted' by the League of Red Cross Societies for World Red Cross Day 1966, namely " No Frontiers for Red Cross". If this could be communicated to and adopted by all of the world's peoples, suffering and distress would be diminished. If we are to be true to the Principles for which Red Cross has stood over many decades and to the humanitarian spirit of its founder, Henry Dunant, we can spare no efforts to alleviate human suffering in the world today."

\section{Nicholas H. PHILLIPS}

Desk Officer for Africa, Development Programme League of Red Cross Societies

\section{Japan}

Mrs. Sachiko Hashimoto, Director of the Japanese Junior Red Cross has sent the Junior Red Cross Bureau of the League a parable written by a member of the Japanese Junior Red Cross. It was submitted by the author, a commercial high school student, to the 1964 Japanese Red Cross national seminar.

It is well known that the dissemination of knowledge on the Geneva Conventions is a subject to which International Conferences of the Red Cross have repeatedly drawn attention. In view of the importance of promoting this dissemination among youth by simple and effective means, we believe that, with the agreement of the League, which passed it on to us, it will be of interest to publish this narrative entitled " $A$ Dialogue between the Old Man and Children". 